\title{
全龍型突発性難聴に対する抗ウイルス療法
}

\author{
平位 知久 ・ 木村 信次 ・藤井 守*
}

\section{Anti-viral Treatment for Three Cases of Sudden Onset Total Deafnesses}

\author{
Tomohisa Hirai and Shinji Kimura \\ (JA Onomichi General Hospital) \\ Mamoru Fujii \\ (Chugoku Electric Power Hospital)
}

\begin{abstract}
The efficacy of anti-viral teatment (acyclovir, $\gamma$-globulin) was assessed in the treatment of three patients with sudden onset total deafnesses. Two of the three patients showed slight improvement in hearing disorders, but the remaining patient showed no improvement. One of the three cases was suspected of having some relation to an infection by herpes simplex virus. A more effective protocol for sudden onset total deafnesses is needed.
\end{abstract}

Key words : anti-viral teatment, acyclovir, $\gamma$-globulin, sudden onset total deafnesses

\section{はじめに}

突発性難聴のなかには，発症と同時に高度の聴力低下 をきたす症例がある.これらは壟型突発性難聴と称され， その聴力予後は不良であることが多い。なかでも全周波 数で聴力閾值が測定できないものは，全壟型突発性難聴 と称され，従来のステロイドを中心とした治療では十分 な効果が上げられていない1)。一方，これらの疾患は，ウ イルス感染が原因としてステロイドは使わず，抗ウイル ス剤，ガンマグロブリン，インターフェロンなどによる 治療を施行し，良好な成績が得られたという報告があ る2)3)。そこで，当科においても全䆍型突発性難聴 3 例に 対し，アシクロビル，ガンマグロブリンなどによる抗ウ イルス療法を施行した。その治療成績について報告する。

\section{対象}

対象は, 平成 13 年 5 月から 8 月までの間に当科を受診 した発症から 2 週間以内の一側性全壟型突発性難聴 3 例
（男性 1 例，女性 2 例）とした。ただし，このうち 1 例は 他院ですでにステロイドの投与を受けていた。一側性か どうかの判断基準として，患側と健側の平均聴力で, $60 \mathrm{~dB}$ 以上の差があるものとした，なお，平均聴力につ いては， $250 \mathrm{~Hz}$ から $4000 \mathrm{~Hz}$ までの平均聴力とした（5 分法).

\section{方 法}

治療内容は，入院の上アシクロビル $750 \mathrm{mg} /$ 日（分 3) の投与を 3 日間行い，明らかな聴力改善が認められなり れば，治療開始 4 日目から非特異的ウイルス療法として ガンマグロブリン製剂 $2.5 \mathrm{~g}$ /日を 5 日間投与した．加療 開始後 8 日目において聴力の改善が得られない場合，引 き続きプレドニゾロン $80 \mathrm{mg} /$ 日からの漸減投与（10 日 間) と，プロスタグランディン $\mathrm{E}_{1} 60 \mu \mathrm{g} /$ 日の投与（14 日 間）を行った。また，低分子デキストラン $500 \mathrm{ml} /$ 日を 入院時より 5 日間投与した. 
検查は, 純音聴力検查のほか, 平衡機能検查（視運動 性眼振検查, 視標追跡検查を含む), 迷路瘦孔検查, 血清 学的検查（単純ヘルペス IgG，帯状疮疹 IgG，正常值は いずれも 2.0 未満), 頭部 MRI 検查を施行した. なお, 血清学的検查においては, ペア血清にて 4 倍以上の変動 がみられた症例をウイルス抗体価陽性とした。

なお，患者本人および家族に対しては，全龍型突発性 難聴は聴力予後が不良であり，ステロイドを中心とした 治療では十分な効果が期待できないことを説明の上，抗 ウイルス療法を優先することで同意を得た.

\section{症例}

症例 $1: 40$ 歳, 男性.

既往歷および家族歷：特記すべき事項なし.

現病歴: 平成 13 年 8 月 19 日就寝前から右耳鳴があり, 8 月 20 日朝加めまいを発症した. 同日, 当科を受診し た. 初診時, 右聴力は全壟となっており, 同日より入院 加療を開始した。単純へルペス IgG 抗体価は，2.0 未満 （正常值）から 5.1 へと有意に上昇していた. 非注視時, 頭位および頭位変換眼振検查では眼振の出現は認めず, 視標追跡検查は平滑, 視運動性眼振検查では解発良好 だった。 入院加療開始後 3 日目においても聴力は改善せ ず,プレドニゾロンおよびプロスタグランディン $\mathrm{E}_{1}$ の投 与を開始した。 8 月 23 日頃にはめまいは軽減した．9月 5 日の聴力検查では, $500 \mathrm{~Hz}$ 以上の音域において, $100 \mathrm{~dB}$
前後で右気導聴力の反応がみられた. 治療は 9 月 10 日に 終了した。 9 月 17 日には右耳鳴は軽減した。 10 月 1 日, 再診時, 右平均聴力は $82 \mathrm{~dB}$ に改善した. 恥力の推移を 図 1 に示した.

症例 $2: 80$ 歳，女性.

既往歴：高血圧.

家族歷：特記すべき事項なし。

現病歷: 平成 13 年 8 月 20 日起床時加左耳鳴とめま いを発症した. 8 月 21 日, 当科を受診した. 初診時, 左 聴力は全壟となっており, 同日より入院加療を開始した。 ウイルス抗体価の有意な上昇は認めなかった. 非注視時 検查, 頭位および頭位変化眼振検查では眼振の出現は認 めず, 視標追跡検查は平滑, 視運動性眼振検查では解発 良好だった。 入院加療開始後 3 日目 (8月 23 日), 500 お よび $1000 \mathrm{~Hz}$ において $110 \mathrm{~dB}$ で反応がみられるにとど まったそそこでプレドニゾロンおよびプロスタグラン ディン $\mathrm{E}_{1}$ を追加投与した. その後, 治療終了直前の 9 月 7 日の聴力検查においても聴力改善はなかった. $100 \mathrm{~dB}$ 付近で反応がみられた。 10 月 1 日, 再診時, 右平均聴力 は $87 \mathrm{~dB}$ に改善していた。 その後, 平成 14 年 1 月 17 日 において聴力は不変であった。 左耳鳴および体動時のふ らつきは継続していた。聴力の推移を図 2 に示した。

症例 $3: 47$ 歳, 女性.

既往歴および家族歴：特記すべき事項なし。

現病歷: 平成 13 年 5 月 21 日起床時から右耳鳴とめま
$125 \quad 250 \quad 500 \quad 1000 \quad 2000 \quad 4000 \quad 8000$

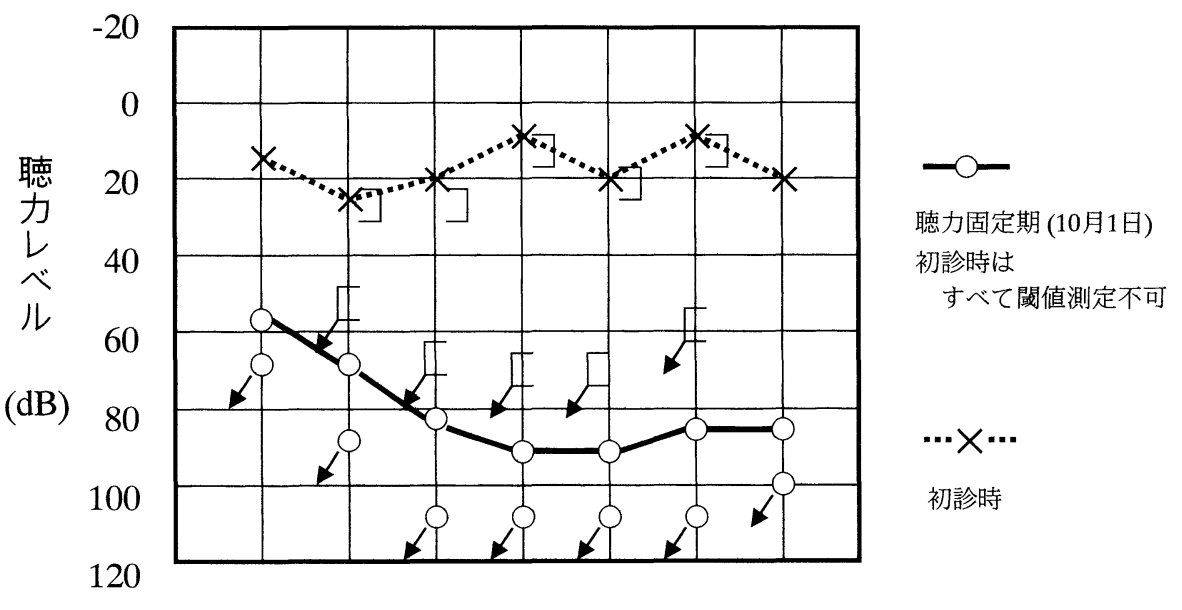

周波数 $(\mathrm{Hz})$

図 1 症例 1 の聴力变化 


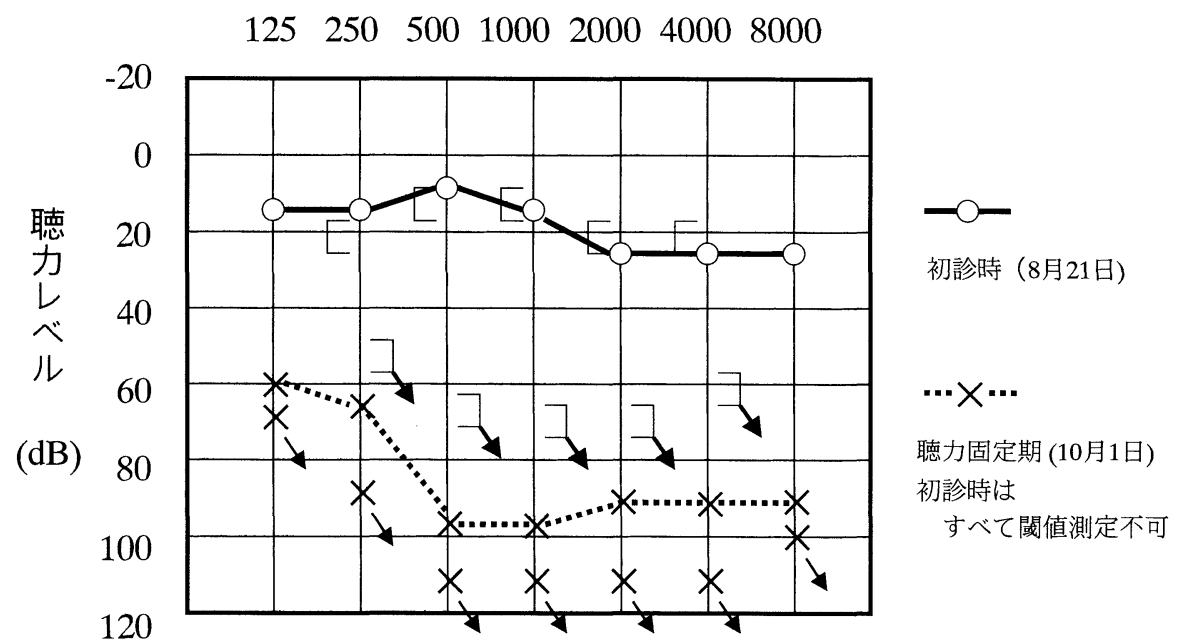

周波数 $(\mathrm{Hz})$

図 2 症例 2 の聴力変化

$125 \quad 250 \quad 500 \quad 100020004000 \quad 8000$

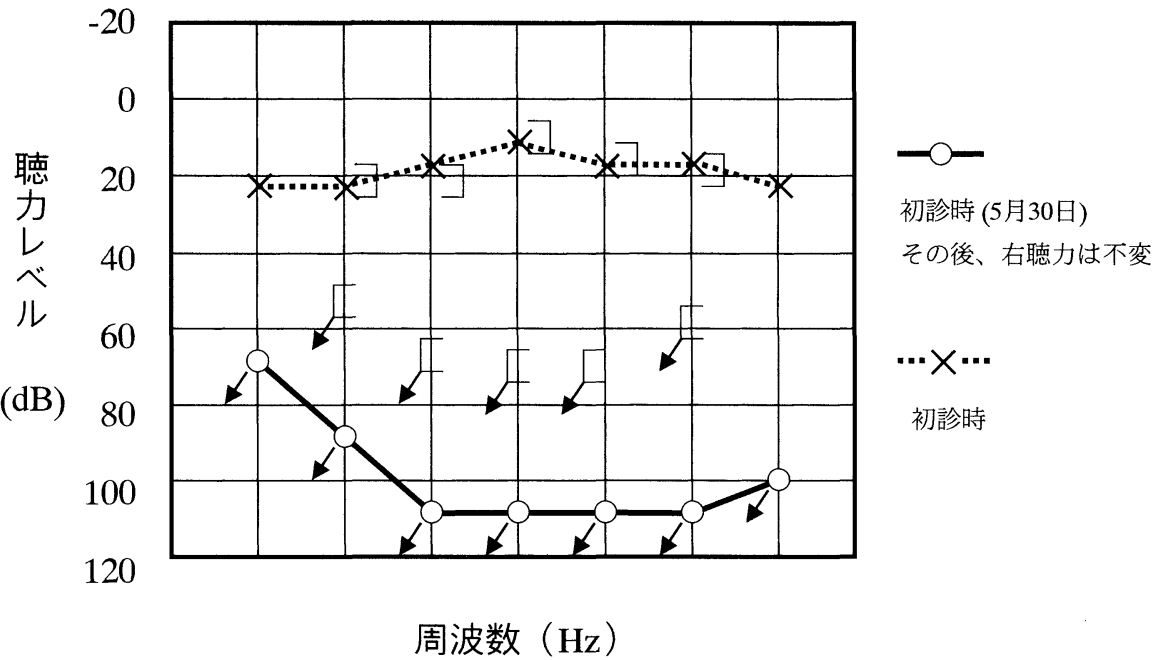

図 3 症例 3 の聴力変化

いを発症した。 5 月 24 日, 近医耳鼻咽喉科を受診し, 右 突発性難聴と診断を受けた。そしてプレドニゾロン $60 \mathrm{mg}$ の点滴漸減投与が開始されたが，聴力は改善しな かった。 そこで 5 月 30 日，当科を紹介受診した。当科初 診時，右聴力は全襲となっており，同日より入院加療を 開始した. ウイルス抗体価の有意な上昇は認めなかった。 非注視時検查, 頭位および頭位変化眼振検査では, 眼振 の出現は認めず，視標追跡検査では軽度断続性，視運動 性眼振検査では解発不良だった。 入院加療開始後も聴力
の改善は得られず，プレドニゾロンおよびプロスタグラ ンディン $\mathrm{E}_{1}$ を追加投与しても聴力改善はなかった。発症 より 1 年以上経過した平成 14 年 8 月 23 日においても聴 力は不変であり, 右耳鳴および頭位変換時のめまいが継 続していた。聴力の推移を図 3 に示した.

なお，以上全 3 症例において，頭部 MRI 検查で異常所 見を認めなかった。 また，経過中に，耳下腺腫脹などム ンプスを疑わせる症状や, 外耳道, 耳介の発疹などの所 見は出現しなかった。 


\section{考察}

全壟型突発性難聴において, 聴力が実用レベルにまで 回復することはまれである. 満島ら ${ }^{1)}$ は，全壟型突発性 難聴新鮮例29耳に対してステロイドを中心とした加療を 行い, その聴力予後は, 治瘉 1 耳 $(3.4 \%)$, 著明回復 10 耳 $(34.5 \%)$, 回復 10 耳 $(34.5 \%)$, 不変 8 耳 $(27.6 \%)$ であったとした．厚生省特定疾患急性高度難聴調查研究 班の基準 ${ }^{4 ）}$ によれは，今回報告した 3 例のうち，2 例は 著明回復と判定され, 満島ら ${ }^{1)}$ の報告と比較しても遜色 のない結果といえる。しかし，全壟型突発性難聴におい て, 平均聴力が $80 \mathrm{~dB}$ 程度まで改善して著明回復と判定 しても，患者側からみれば実用聴力からはほど遠い。し たがって，全壟型突発性難聴においては，この基準は必 ずしも患者側の現状を反映しているものではないと思わ れる.

突発性難聴は, ウイルス感染やその再活性化にあると いう立場から, 従来のステロイド治療ではない治療を行 い，良好な成績をおさめたとする報告が散見されるよう になってきた．金丸ら ${ }^{2)}$ は， $70 \mathrm{~dB}$ 以上の高度突発性難 聴に対してインターフェロン $\alpha$ の筋肉注射を行い, 11 例 中 9 例で治癒, 2 例で著明回復がみられたと報告した. ま た,このらち 1 例で帯状疱疹抗体価, ほか 1 例で単純へ ルペス抗体価の上昇を認めたとした．黑川ら33は４４例 の高度感音難聴例を報告し，そのうち 2 例はステロイド による治療後全襲となったが, 残りの 2 例はステロイド により聴力が悪化したもののアシクロビルまたはガンマ グロブリンの使用により聴力の改善がみられたとした. このうち 1 例で単純ヘルペス抗体価の上昇，もう1例で 単純ヘルペス抗体価および帯状疱疹抗体価の上昇を認め たとした．また，高橋ら5）は，ステロイド投与開始後， 聴力が悪化した急性感音難聴症例に対し, 免疫グロブリ ン製剤とプロスタグランディンの投与に変更したとこ ろ，聴力の改善がみられたとした。この症例においては インフルエンザとパラインフルエンザの抗体価が高值 だった，今回の検討においては，症例 1 において，単純 ヘルペス IgG 抗体価の有意な上昇を認めた. 以上より, 聾型または全壟型突発性難聴においては，ウイルス感染 が病態の中心である可能性が示唆される.したがって, これらの疾患に対しては，従来のステロイドを早期に投 与する治療ではなく，抗ウイルス療法を念頭においた治 療吕望ましいと考えられる，そこで，今回，全壟型突発 性難聴 3 例に対して，ステロイドを投与せず，アシクロ
ビル，ガンマグロブリンを中心とした加療を行った．し かし，聴力の早期改善はみられなかった。そこで，治療 開始 9 日目から従来のステロイド治療に切り替えた。そ の結果, 症例 1 と症例 2 では最終的に聴力は軽度改善し た. 一方で, 症例 3 は全聾のままであった. ウイルス感 染による突発性難聴の機序としては，有毛細胞に対する 不可逆性障害, 血管条におけるウイルス粒子の増殖, 蝸 牛神経に対する神経炎, 蓋膜の剥離などが考えられてい る. 有毛細胞は再生不能の細胞であるから, 有毛細胞に 対するウイルス感染により生じた突発性難聴であれば, 聴力の改善は望めない6). 症例 1 と 2 では軽度ではある が聴力の改善がみられたことから，これらの症例は必ず しも不可逆性の変化に陥っていてはいなかったと考えら れる.しかし，全壟型突発性難聴の原因がウイルス感染 によるものとしても, 今回の検討においてアシクロビル とガンマグロブリンによる抗ウイルス療法では十分な聴 力改善効果を得ることはできなかった. 今後, 全襲型突 発性難聴に対するより有効な治療法の開発が望まれる.

\section{まとめ}

1. 全壟型突発性難聴 3 例に対して抗ウイルス療法を 行った.

2. 1 例において, 単純ヘルペス IgG 抗体価が有意に上 昇していた.

3. 発症初期に抗ウイルス療法を行った2例はわずかに 聴力が改善した。

4. 全竩型突発性難聴に対して,より有効な治療法の開 発が望まれる。

\section{参考文献}

1）満島準子，鈴木幹男，北島和智，他：壟型，全䆍型突発性 難聴の予後.耳鼻臨床 $94: 1067 \sim 1072 ， 2001$

2）金丸眞一，福島英行，中村一，他：インターフェロンに よる突発性難聴の治療. 耳鼻臨床 88：1123 1127, 1995.

3）黑川泰資, 山浦 薰: 壟型突発性難聴の 4 症例. 耳鼻臨床 $91: 221 \sim 225,1998$.

4）柳田則之：突発性難聴に対するステロイド治療の検討．厚 生省特定疾患 急性高度難聴調查研究班 昭和59年度研究 業績報告書. 79 頁, 1985 .

5）高橋將範，硲田猛真，榎本雅夫，他：興味ある経過をとっ た急性感音難聴例. 耳鼻臨床 $92: 1181 \sim 1186,1999$.

6）田中克彦，福田 諭：突発性難聴とウイルス感染. Otol Jpn 4: $130 \sim 136,1994$.
原稿受付：平成15年 3 月 28 日 原稿採択 : 平成15年 6 月11日 別刷請求先 : 平位知久 T722-8508 尾道市古浜町7-11 厚生連尾道総合病院耳鼻咽喉科 